The International Journal Of Engineering And Science (IJES)

|| Volume || 6 || Issue || 1 || Pages || PP 52-59 || 2017 ||

ISSN (e): $2319-1813 \operatorname{ISSN}$ (p): $2319-1805$

\title{
Impact of Macroeconomic Factors on Share Price Index in Vietnam's Stock Market
}

\author{
Vuong Quoc Duy ${ }^{1}$ and Le Long $\mathrm{Hau}^{2}$
}

\begin{abstract}
This paper investigates the macroeconomic determinants of share price in the stock market of Vietnam. The investigation was conducted by using a VECM econometric methodology and revealed thatVietnam's stock market prices are chiefly determined by economic activities: market price index, inflation, money supply and exchange rate. An increase in market price index and money supply makes share price, while the increase of inflation (CPI) and exchange rate reduces share price. The study's result showed that Vietnam's stock market can be replaced by investors of foreign currency (USD), while the exchange rate tends to rise.
\end{abstract}

Keywords: Macroeconomic factors, Vietnam's stock market, VECM.

Date of Submission: 11 July 2016

$\longrightarrow$ Date of Accepted: 26 January 2017

\section{INTRODUCTION}

Nowadays, according to the common trend of the world, besides the main income of jobs or the own production and business, the Vietnamese also have additional income from the sources such as making deposits in the banks, investing in foreign currency, trading in gold, investing in business of real estate and stocks. Investing in the stock market brings the high profitability but a lot of risks. This investment currently has the best transparence in Vietnam, and enough liquidity to get the difference of business in short term as well as to choose the good and stable codes for the long-term investment in difficult stages. Based on the advantages above, the stock investment becomes more and more popular and plays a very important role in the financial system of country.

Since then, most investors of stock care that if the estimation tools are used to forecast the trend of stock prices. "Efficient market is in which the stock price is adjusted immediately when new sources of information appear" (Fama, 1970), or in other words, current price of stock shows all information of that stock. Efficient Market Hypothesis - EMH supplied the extremely important basis of theory for those making policies and investors of stock. Thence, those who making policies can freely execute the macroeconomic policies of country without caring about these policies changing the nature of stock market because they only affect the stock price index. In contrast of EMH's conclusion, real evidences point out that the important macroeconomic factors can forecast the fluctuation of stock price index. Researches of Maysami et al. (2004), Gan et al. (2006), Nisa and Nishat (2012), Truong Dong Loc (2014) most define that macroeconomic factors obviously affect income and the fluctuation of stock price index. These factors are Gross National Product, inflation rate, interest rate, gold price, exchange rate,...

In addition, one finding shows: it is forecasted that increase of basic interest rate of Federal Reserve System will make the price index of stock market in the world decreased (Nguyen Ngoc Thach, 2015). Explanation is that if interest rate in the market of America increases, the international investors will invest in this market and decrease the invested capital in the market of other countries. However, based on the viewpoint of an investor, increasing the basic interest rate of America means the US dollar is more powerful other currencies (or increase of exchange rate VND/USD), this makes investors holding USD sell USD and transfer their investment in other forms of investment including the stock investment, so it leads to the increase of stock price index. This argument is suitable to the research of Eita (2012) if it is said that the exchange rate has a positive correlation with the stock price but against with research of Maysami et al. (2004), Phan Thi Bich Nguyet and Pham Duong Phuong Thao (2013).

In summary, in the developing economy and a quite new stock market of Vietnam, macroeconomic factors which are market price index, consumer price index, money supply and exchange rate has a powerful and immediate (nearly immediate reflection to the international information) impact (both positively and negatively) on the fluctuation of share price in the stock market. Therefore, it is essential to implement the research "Impact of macroeconomic factors on share price index in Vietnam'sstock market"so as to find the mutual impact of

\footnotetext{
${ }^{1}$ Associate Professor Doctor, College of Economics, Can Tho University, Vietnam

${ }^{2}$ Doctor, College of Economics, Can Tho University, Vietnam
} 
investment forms and evaluate changes in behavior of investors in the stock market. This topic is different from the previous ones which foreign currency and stock are considered the interchangeable channels of investment, so it is expected that this topic will find the correlation between exchange rate and stock price index generally and share price index specifically. Thence, managers can have the appropriate macroeconomic policies and investors will make more reasonable decisions in business of share at the current economy.

\section{THEORETICAL BASES AND RESEARCH METHOD}

\subsection{Theoretical bases \\ 2.1.1 Concept of stock market}

Stock market is a place which supply and demand of kinds of stockgathers to determine the price. Quantity of every kind of stock is transacted in the market.

Specifically, stock market is defined as a place which saving sources gather to deliver to those who need to use that saving sources with the prices which users are ready to pay. In other words, stock market will gather and deliver these sources of investment, making capital of production in the economy increased, and leading to establish a developed and prosperous economy.

According to the definition above, stock market is not an organization implementing the purchase or selling of kinds of stock. Stock market is only a place of transaction in which the stock trading is implemented by brokers. So, stock market is a transaction place (purchase - sell) of stock of brokers, not of those who want to buy or sell stock. If someone wants to purchase or sell stock, they will not directly implement this and these activities will be made by their brokers in the stock market. Stock price is established objectively according to the two-way auction system. Purchasing brokers compete with the other purchasing ones to take the lowest price and selling brothers compete with the other selling ones to get the highest price. Therefore, stock market has the highest freedom.

\subsubsection{Stock price index}

Stock price index is a measure reflecting the general fluctuation of stock in the stock market. Establishment of price indexes is mainly aimed at forecasting trends of market which creates a basis for purchasing or selling stock at certain times. This is very important information to the listing companies, investors and those evaluating the markets and is barometer of economy.

\subsubsection{Consumer price index}

Consumer price index (CPI) is calculated in percentage to show the relative change of price of goods according to the time. The change is only relative because this index is based on a basket of consumer goods which is representative for all consumer goods. This is the most popular item used to measure price and change of price which is specifically inflation.

CPI measures inflation experienced by consumers in their daily spending. Increase of CPI index is almost considered as "inflation rate". This index is used by retailers in forecasting price in the future, by bosses in calculating the salary and by government in determiningthe increase level of social protection fund.

Change of price of goods and services in the market directly affects the securities which have fixed interest rate. If prices increase, the real value of fixed interest will be lower and that makes profitability of securities decreased. Inflation also has impact on salary, allowance, and retirement because they are fixed payments. Those receiving retirement pension will witness their money which gradually "disappears" due to the decreased purchasing power by the time.

\subsubsection{Money supply and stock market}

Money supply and stock market obviously have a relation in the same direction which is manifested through monetary policy.

Expansionary policy:

Expansion of money supply leads to the increase of goods consumption and the raise of using financial assets including stock. When money supply increases, the outstanding liquidity will affect the stock market strongly because the impact of monetary policy is quite quick and direct. Expansionary policy makes interest rate of economy as well as discount rate of stock decreased which leads to the increase of expected price and income.

\section{Contractionary policy:}

That interest rate becomes higher due to affect of contractionary policy often makes the bad impact on stock market. The reasons are: first, making securities' price decreased due to increase of discount rate in pricing models; secondly, making securities having fixed income be a more interesting choice which reduces liquidity in share; thirdly, reducing the borrowing tendency to increase the investment of stock; and finally, increasing the operation expense of enterprises which affect the earning of company. 
Research of Friedman and Schwartz (1963) shows the initial explanation about the relation between money supply and income of stock. Since then, increase of money supply will raise the liquidity and credit for investors of stock leading the higher price of stock. Jiranyakul (2009), Mukherjee and Naka (1995), Kwon and Shin (1999) realized the positive relation between money supply and fluctuation of stock price, which means increase of money supply will lead to the more stable development of stock market.

\subsubsection{Exchange rate and stock market}

Exchange rate helps adjust and balance supply and demand of assets. Investors will sell some foreign assets which currently make them less interesting, if they want to purchase more domestic assets. This leads the high valuation of domestic currency or decreased exchange rate (because exchange rate is determined as price of a currency unit calculated based on price of other currency - domestic), so relation between stock price and exchange rate is in the opposite direction.

Increased price of domestic assets makes investors raise their need about currency, and this leads to the increase of interest rate. Other operation making relation between stock price and exchange rate be in the opposite direction is more foreign investment in domestic assets which making stock price increased. This is also the cause of high valuation of domestic currency.

When approaching exchange rate as an asset (price of a unit of foreign currency) in asset market, Gavin (1989) in monetary model defined that exchange rate and share price has a weak relation or completely has no relation. Like price of other assets, exchange rate is also determined by expected exchange rate in the future. Factors affecting the future value of exchange rate will influence current exchange rate. Factors creating the change in exchange rate can be different from factors making the change in price of shares, and in this case, these assets above will not have any relation. When price of shares and exchange rate is affected by some factors, we hope that there will be a connection between two variables. The connection is not established if: domestic currency is undervalued to raise the value of enterprises exporting goods, but when these enterprises import much which raising expense of input abroad, share price cannot increase, and at that time, products' expense of enterprise will increase which reduces the competition of enterprises.

Otherwise, share price of enterprises which do not export their products to other countries but import the raw material will decrease when domestic currency is undervalued, and it causes the decrease of revenue or earning.

\subsubsection{Stock market of Vietnam}

In 2000, stock market of Vietnam is marked by operating Ho Chi Minh Securities Trading Center on July $20^{\text {th }}$, 2000 (now Ho Chi Minh City Stock Exchange - HOSE) and trading commenced on July $28^{\text {th }}$, 2000. At that time, VN-Index opened at 100 points with two kinds of listed share (REE and SAM) in capital of 270 billion dong and few listed government bonds (Ho Chi Minh City Stock Exchange, accessed on September $24^{\text {th }}, 2012$ ). Hanoi Stock Exchange (HNX), formerly the Hanoi Securities Trading Center (Hanoi STC) was launched in March $08^{\text {th }}, 2005$. Unlike Ho Chi Minh City Stock Exchange (a place listing and trading securities of big companies), Hanoi Stock Exchange is a "playground" of small and medium-sized enterprises which is manifested through indicator of HNX-Index share.

Besides VN-Index of HOSE and HNX-Index of HNX, stock market of Vietnam has an indicator only for the Unlisted Public Company Market (UPCoM) aimed at broadening the market.

\subsection{Research method}

\subsubsection{Previous researches}

In developed countries, research of Maysami et al. (2004) is about impact of inflation, exchange rate, index of industrial production and money supply on stock market of Singapore from January 1989 to December 2001. The result of research showed that exchange rate and share price have a relation in opposite direction. Research of Garefalakis (2011) about stock market of HongKong from January 2002 to August 2009 which is to find other factors such as oil price, gold price, and America stock index and he concluded that factors used in the model is meaningful, which includes the finding of negative correlation between gold price and share price in the market. This seems opposite with the real situation in Vietnam, because gold price and share price fluctuate in the same direction, according to the visual observation in early months of 2015.

Besides researches about stock market in developed countries as Singapore and Hong Kong, the research about stock market in Namibia implemented by Eita (2012) also showed positive correlation between exchange rate and share price. Because economy of Namibia is developing and has a lot of instabilities with incomplete law system, investment in government bonds is very popular thanks to high profit and little risks. Vietnam is a developing country which has many similar characteristics with Jordanian, so it may be that factors above also have similar impacts on stock market of Vietnam.

To the domestic researches, Phan Thi Bich Nguyet and Pham Duong Phuong Thao (2013) studied the effect of some macroeconomic factors on market price index of Ho Chi Minh City Stock Exchange in the period 7/2000 
- 9/2011. This proves that exchange rate has opposite relation with the change of stock price index. It contrasts with argument of author when expecting to find the positive correlation between exchange rate and market price index.

Nguyen Minh Kieu and Nguyen Van Diep (2013) studied the effect of relation between macroeconomic factors and fluctuation of stock market from 1/2004 to 12/2011. The research showed that gold price has positive correlation with stock price index, and exchange rate does not affect the stock market of Vietnam. Result about positive relation between gold price and market price index is different from research of Garefalakis (2012) but appropriate with Vietnam economy. That exchange rate does not affect stock market is controversial because this result contrasts with other researches.

In conclusion, experienced researches pointed out that macroeconomic factors such as market price index, consumer price index, exchange rate and money supply have a big impact on share price index in the stock market. However, there is a difference among researches of Vietnam and other countries; this is caused by characteristics between developing countries and developed countries. Therefore, research about impact of macroeconomic factors on the fluctuation of Vietnam stock market will express details about this issue.

\subsubsection{Method of data collection}

Secondary data collected from the source which begins 01/2006 to 12/2015 is manifested in the following table:

Table 1. Summary of variables in the model and source of data collection

\begin{tabular}{|l|l|c|l|}
\hline \multicolumn{1}{|c|}{ Variable } & \multicolumn{1}{|c|}{ Description } & Unit & \multicolumn{1}{|c|}{ Source of collection } \\
\hline VNI & $\begin{array}{l}\text { Market price index which is monthly } \\
\text { average in HOSE }\end{array}$ & Point & $\begin{array}{l}\text { Website of Ho Chi Minh City Stock } \\
\text { Exchange }\end{array}$ \\
\hline CPI & Monthy consumer price index & $\%$ & $\begin{array}{l}\text { Website of General Statistics Office } \\
\text { of Vietnam }\end{array}$ \\
\hline EX & $\begin{array}{l}\text { An interbank exchange rate (monthly } \\
\text { average) of Vietnam dong (VND) to the } \\
\text { United States dollar (USD) }\end{array}$ & VND/USD & Website of State Bank \\
\hline M2 & Money supply & Billion dong & $\begin{array}{l}\text { Elibrary on website of International } \\
\text { Monetary Fund }\end{array}$ \\
\hline
\end{tabular}

Variables VNI, CPI, EX, $\mathrm{M}_{2}$ and GP are used as the natural logarithm to reduce the high dispersion and have some observations having a usual value of original data.

\subsubsection{Method of data analysis}

Researching the impact of monthly average index of market price in HOSE (VNI), monthly consumer price index (CPI), an interbank exchange rate (monthly average) of Vietnam dong (VND) to the United States dollar (USD) (EX), money supply (M2) implemented by using stata software will help determine macroeconomic factors really making impact on dependent variables and level of effect. This method will eliminate inappropriate variables and limit unnecessary variables in the model so that result of estimation is exact. One of hypotheses of classical linear regression model is that independent variables must be non-random variables. If we estimate a model with chronological series in which independent variables are non-stationarity, hypotheses of ordinary least square will be violated (mathematical expectation, variance and covariance do not change chrologically) which makes $t$ and $p$ test inefficient (called spurious regression). So, Augmented Dickey - Fuller test (ADF) is initially used to test the existence of unit root of chronological sequence between stock price index and macroeconomic factors. This is considered as the initial step used in the model. If chronological sequence does not contain unit root or is called stationarity, chosen variables can meet the requirement of used method. In contrast, if result of unit root test shows variables which are non-stationarity sequence, integration test is implemented because the linear combination of non-stationarity chronological sequence can be a stationarity sequence and those non-stationarity chronological sequences are considered cointegration. After determining that data is stationarity sequences, it is necessary to use regression model to define impact of share price index on dependent variables, impact of market price index, consumer price index, exchange rate and money supply on independent variables and impact of independent variables on explanatory variables.

Relation between independent variables and dependent variables is manifested on the following equation:

$\mathrm{SP}=\beta_{0}+\beta_{1} \mathrm{VNI}+\beta_{2} \mathrm{CPI}+\beta_{3} \mathrm{EX}+\beta_{4} \mathrm{M}_{2}+\mathrm{e}$

SP: Share price index

VNI: monthly average index of market price in HOSE

CPI: Monthly consumer price index

EX: an interbank exchange rate (monthly average) of Vietnam dong (VND) to the United States dollar

$\mathrm{M}_{2}$ : Money supply 
From the experienced researches, the expectation table is established about sign between independent variables and dependent variables as follows:

Table 2. Correlated expectation between factors in the model and VN index

\begin{tabular}{|c|c|l|}
\hline Variables & Expectation & \multicolumn{1}{|c|}{ Experienced researches } \\
\hline CPI & - & Al-Sharkas (2004), Nisa (2012), Nguyen Minh Kieu and Nguyen Van Diep (2013) \\
\hline EX & - & Eita (2012) \\
\hline VNI & + & Nguyen Minh Kieu and Nguyen Van Diep (2013) \\
\hline $\mathrm{M}_{2}$ & + & $\begin{array}{l}\text { Maysami et al. (2004), Nisa (2012), PHan Thi Bich Nguyet and Pham Duong Phuong Thao } \\
(2013)\end{array}$ \\
\hline
\end{tabular}

\subsection{Result of stationarity test}

\section{RESULT OF RESEARCH}

Figures in the model are chronological sequence of data and characteristic of this sequence is stationarity. The regression model on non-stationarity sequence may lead to obtain inaccurate or unbelievable results, although it is seen that result seems good, which is called spurious regression. Therefore, it is essential to test the stationarity of sequences of figure in the model in the analysis of figures which are chronological sequences. One of popular methods in testing the stationarity of figure sequences is unit root test supposed by Dickey and Fuller. Hypothesis of unit root test is: $\mathrm{H} 0: \beta=0$ non-stationarity chronological sequence. $\mathrm{H} 1: \beta=1$ stationarity chronological sequence. In unit root test, the tested value is not under on normal distribution and is based on probability distribution $\tau$ (tau statistic, $\tau=$ estimated value of coefficient/ estimated measurement uncertainty of coefficient). Critical value $\tau$ is determined based on available table of values of Mackinnon (1996). To test the hypothesis H0, we compare the calculated value of $\tau$ test with critical value $\tau$ of Mackinnon and conclude the stationarity of figure sequences. Specifically, ifabsolute value of calculated value is greater than absolute value of critical value, hypothesis $\mathrm{H} 0$ will be eliminated and $\mathrm{H} 1$ will be accepted. This means the data sequence having stationarity. In contrast, if hypothesis $\mathrm{HO}$ is accepted, the data does not have stationarity. Absolute value of calculated value $\tau$ most is greater than absolute value of $\tau$ value found in the table. So, it has a basis to eliminate hypothesis $\mathrm{H} 0$ or in other words, sequence of figure is stationarity sequence.

Table 3.Result of unit root test

\begin{tabular}{|l|c|c|}
\hline \multirow{2}{*}{ Macroeconomic variables } & \multicolumn{2}{|c|}{ ADF Test } \\
\cline { 2 - 3 } & Latency & ADF Statistics \\
\hline VNindex & 1 & $-1.93^{* *}$ \\
\hline M2 & 1 & $-2.89^{* * *}$ \\
\hline Exchange rate & 1 & $-2.38^{* *}$ \\
\hline CPI & 1 & $-4.03^{* * *}$ \\
\hline
\end{tabular}

Note: (***), (**), (*): having statistical meaning at 1\%, 5\% and $10 \%$

Result shows variables in the model have stationarity. So, integration test is implemented.

\subsection{Result of integration test}

Although result of unit root test pointed out that data in the model is non-stationarity sequence of figure which makes regression of this chronological sequence result in spurious regression, Engle and Granger said that combination of non-stationarity sequences will create a stationarity sequence and that non-stationarity sequence is called integration. Therefore, it is based on method of Johansen to implement the integration test for these non-stationarity chronological sequences. Hypothesis of integration test is: H0: There is not a relation of integration between chronological sequences; H1: There is a relation of integration between chronological sequences. At the meaning level of 5\%, we will compare value of Trace Statistic and value of Critical Value to decide whether we should eliminate or accept hypothesis H0. If Trace Statistic is smaller than Critical value, hypothesis $\mathrm{H} 0$ will be accepted. It means that there is not a relation of integration between chronological sequences.

Table 4: Result of integration test

\begin{tabular}{|l|l|l|}
\hline \multicolumn{1}{|c|}{ Hypothesis H0 of Johansen test } & Trace Statistic & Critical Value \\
\hline There is not a relation of integration between chronological sequences & 50.0555 & 47.21 \\
\hline There is one relation of integration between chronological sequences & 19.3788 & 29.68 \\
\hline There is two relation of integration between chronological sequences & 6.9296 & 15.41 \\
\hline There is three relation of integration between chronological sequences & 0.0024 & 3.76 \\
\hline
\end{tabular}

Result shows that if latency is 1 , there will be at least 1 relation between variables in the model. 


\subsection{Result of regression model}

After using the stationarity test and integration test, regression model will be implemented. Result of regression model shows:

- Market price index: at the meaning level of $1 \%$ and in condition of unchangeable other factors; we can realize the positive effect on share price index. Research of Nguyen Minh Kieu and Nguyen Van Diep (2013) also showed the positive relation between market price index and share price index at the meaning level of 5\% and this affects in long time.

- Money supply: In condition of unchangeable other factors, at the meaning level of 10\%, money supply has positive impact on share price index. This result is similar to previous researches about the correlation between money supply and stock market. Increase of money increase is a condition to create redundancy of total method of payment. This is also condition so that cash flow moves to the stock market, which making stock price index increased. According to research of Phan Thi Bich Nguyet and Pham Duong Phuong Thao (2013) at the meaning level of 5\%, money supply and share price index have the positive relation.

- Exchange rate: At the meaning level of $10 \%$ and in condition of unchangeable other factors, it is realized that exchange rate has negative impact on share price index. Vietnam is usually a country having the trade deficit and not having the really developed science and technology, so machines, material,... are mainly imported from foreign countries. USD (the US dollar) is foreign currency which is more powerful than VND (domestic currency), so price of many products is determined based on USD, loan calculated in USD is used by a lot of enterprises, people consider the USD holding as a way to avoid risks. These issues above lead to the devaluation of VND when an exchange rate increase, which makes investors have unsafe feeling. It is considered as a signal that macroeconomic instability happens, so stock market will be decreased. According to research of Eita (2012) in Namibia, at the meaning level of 5\%, exchange rate has an impact in opposite direction on share price in thestock market. Therefore, exchange rate (represented by USD) can be considered as an investment channel which may replace stock market.

- In condition of unchangeable other factors, at the meaning level of $10 \%$, consumer price index has negative impact on share price index. The result is also appropriate with research of Al-Sharkas (2004); at the meaning level of 1\%, inflation (represented by CPI) affects the share price positively. Researches of Nisa (2012), Nguyen Minh Kieu and Nguyen Van Diep (2013) also pointed out that at the meaning level of 1\%, consumer price index has negative impact on share price index.

Table 5. Estimated result of regression model

\begin{tabular}{|c|c|c|c|c|c|c|c|c|}
\hline \multirow{3}{*}{$\begin{array}{l}\text { Independ-ent } \\
\text { variables }\end{array}$} & \multicolumn{8}{|c|}{ Dependent variables } \\
\hline & \multicolumn{2}{|c|}{ Vnindex } & \multicolumn{2}{|c|}{ M2 } & \multicolumn{2}{|c|}{ CPI } & \multicolumn{2}{|c|}{ Exchange rate } \\
\hline & Coeffici-ent & $\mathrm{P}$ & Coeffici-ent & $\mathrm{P}$ & Coeffici-ent & $\mathrm{P}$ & Coeffi-cient & $\mathrm{P}$ \\
\hline Vnindex $(-2)$ & \multicolumn{2}{|l|}{-} & 0.0012 & 0.946 & 0.0036 & $0.09 *$ & -2.075 & $0.034^{*}$ \\
\hline $\mathrm{M}_{2}(-2)$ & 0.849 & 0.437 & \multicolumn{2}{|l|}{ 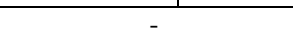 } & 0.0305 & $0.097 *$ & 7.64 & 0.312 \\
\hline CPI (-2) & -3.958 & 0.635 & -2.205 & $0.078 *$ & \multicolumn{2}{|c|}{-} & 6.78 & 0.906 \\
\hline Exchange(-2) & 0.0107 & 0.516 & 0.0013 & 0.542 & -0.00054 & $0.051^{*}$ & 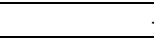 & \\
\hline
\end{tabular}

Note: (***), (**), (*): having statistical meaning at 1\%, 5\% and $10 \%$

\subsection{Conclusion}

\section{CONCLUSION AND RECOMMENDATION}

This paper researches the impact of macroeconomic factors on share price index in the stock market of Vietnam in the period $01 / 2006-12 / 2015$. The research is implemented through considering again theory and experiences concerned. VECM model is applied to analyze the index. The analysis shows that share price index in the stock market of Vietnam is affected by macroeconomic factors which are: market price index, consumer price index, money supply and exchange rate. The research also points out the positive relation between share price index with market price index and money supply. Increase of money supply and economic activities makes price of stock market raised. It shows that the increase of money supply leads to the development of economy based on that cash flow rises and share price will get benefits from the expansionary policy. Thence, money supply in economic activities increases will bring benefits to price of stock market. Increase of inflation (represented by CPI) makes share price of stock market decreased. This supplies evidence to support Fama (1981) and is contradictory with the general Fisher hypothesis. Results mean that share price will be reduced if there is the decrease of economy which is forecasted by the increase of inflation. That increase of exchange rate makes share price decreased shows the raise of exchange rate will lead to the change of cash flow, and almost investors will trading in USD. The effectiveness of investment and earning of stock market will decrease.

Like the other stock markets in the world, stock market of Vietnam is strongly influenced by macroeconomic factors. Therefore, it is necessary to have positive methods adjusting macroeconomic factors and making stock market of Vietnam more and more developed. 


\subsection{Recommendation}

\subsubsection{Stabilizing the exchange rate}

Exchange rate plays an important role in the operation of economy. At present Vietnam has been having policies attracting the invested capital from foreign countries; especially the indirect capital through drafting contents that foreign investors are allowed to purchase stocks and contributed capital to own $51 \%$ authorized capital of stock trading organizations operating at present; andto establish new stock trading organizations which having $100 \%$ foreign capital or purchase to own $100 \%$ foreign capital of stock trading organizations operating in Vietnam. Through the capital attraction policies, stabilizing the exchange rate will contribute to make policies attracting invested capitals from foreign countries more efficient; bring belief about the stable and favorable trading environment to investors; and create the later foundations in attracting more foreign capital to invest and develop the stock market in the future. To achieve the purpose of stabilizing exchange rate, economic activities need to be implemented to create a lot of foreign currency's revenue sources which are: improving balance of international payments, raising foreign-exchange reserves,... State Bank can use these revenue sources to adjust and maintain exchange rate to the stability when necessary. Besides, it is essential to implement the macromanagement of concerned authorities aimed at supplying timely and appropriate policies of adjustment when there are fluctuations in the economy affecting the exchange rate. The good implementation of solutions above will help impulse the economic potential and have enough tools to maintain the stability for foreign exchange market, against external shocks to stabilize macroeconomics, and limit the unusual impacts of macroeconomic factors on share price index.

\subsubsection{Flexibly operating the monetary policies}

Operating the monetary policies plays an important role in the economy, which helping the economy achieve macroeconomic purposes which are to curb the inflation, stabilize exchange rate and develop the economy in the future. Through the change in money supply, monetary policy will make impact on objects in the economy, and money supply and investors' decision in the stock market. When the expansionary policy is implemented, money supply will make the general situation of interest rate decreased. The low interest rate does not encourage investors to deposit in banks and makes investors to need more loans due to their lower expenses and find more interest investment channels including stock market. Therefore, the increase of stock need leads to the raise of share price.

\subsubsection{Controlling the inflation and adjusting money supply to the stability}

It is necessary to have a synchronous and flexible combination between monetary policy and financial policy to avoid the negative impact influencing the efficiency of every policy. Inflation is affected by many reasons which are structure of economy, export and import, credit policies of banks or financial policy... However, inflation is mainly manifested in money supply of economy, it is necessary to have solutions making impact on money supply to control the inflation. These solutions are to apply contractionary policy, gather credit policies to the key activities of economy... This needs to have a cooperation of State Bank and credit agencies so as to ensure the stable operation of banks and achieve the purpose which is inflation control. It is essential to promote information collection, process data about inflation quickly and accurately to supply enough information for evaluating the real situation of economy and production and business, timely giving solutions in the unfavorable circumstances; and reducing risks of loss.

\section{List of Vietnamese documents:}

\section{REFERENCES}

[1]. Nguyen Minh Kieu and Nguyen Van Diep, 2013. Relation between macroeconomic factors and fluctuation of stock market: evidences researched in Vietnam market. Journal of Science and Technology Development, No. 3, page 86100.

[2]. Phan Thi Bich Nguyet and Pham Duong Phuong Thao, 2013. Research of impact of macroeconomic factors on stock market of Vietnam. Journal of Development and Integration, No. 8, page 34-41.

[3]. Truong Dong Loc, 2014. Factors influence the change of share price: Evidences collected from Ho Chi Minh City Stock Exchange. Journal of Science of Cantho University, No. 33, page 72-78.

List of English documents:

[4]. Al-Sharkas, A. (2004), The Dynamic Relationship Between Macroeconomic Factors and the Jordanian stock market. International Journal of Applied Econometrics and Quantitative Studies, 1: 97-114.

[5]. Chen, N.F. et al., 1986. Economic Forces and the Stock Market. Journal of Business, 59: 383 - 403

[6]. Eita, J.H. 2012. Modelling Macroeconomic Determinants of Stock Market Prices: Evidence from Namibia. The Journal of Applied Business Research, 28(5): 871-884.

[7]. Fama, E.F., 1970. Efficient Capital Markets: A Review of Theory and Empirical Work. Journal of Finance, 25: 383417. 
[8]. Garefalakis, A.E. et al., 2011. Determinant factors of Hong Kong stock market. International Research Journal of Finance and Economics, 62: 50-60.

[9]. Gan, C. et al., 2006. Macroeconomic Variables an Stock Market Interactions: New Zealand Evidence. Investment Management and Financial Innovations, 4(3): 89-101.

[10]. Maysami, R.C. et al., 2004, Relationship between macroeconomic variables \& stock market indices: Cointegration evidence from Stock Exchange of Singapore's All-S sector indices. Journal of Pengurusan, 24: 47-77.

[11]. Nisa, M.U. and Nishat, M., 2012. The determinants of stock prices in Pakistan. Asian Economics and Financial Review, 1(4): 276-291. 